\title{
EXPERIENCES AND PERCEPTION OF ECONOMIC HARDSHIP AND RURAL PEOPLE'S OPINION. A STUDY IN TWO EGYPTIAN VILLAGES
}

( Received: 12.10. 2008 )

\author{
By \\ A. T. Elbendary \\ Department of Rural Sociology and Agricultural Extension, Faculty of Agriculture, \\ Cairo University, Giza, Egypt.
}

\begin{abstract}
During the last decades, Egypt experienced a profound economic transformation including privatization, macroeconomic stabilization, and trade openness. Despite the impressive performance in implementing economic reforms, Egypt faces considerable challenges in the area of poverty and food security. This study questioned the extent to which rural people's experiences and perceptions of economic conditions are associated with their opinions toward Government policies and performance. The study was conducted on a randomly selected sample of 165 families from two villages (El-Talat village at Fayoum Governorate, and in Kafr-Mekawy village at Sharqia Governorate). The data were collected by personal interview using a pre-tested structured questionnaire. The study revealed that rural people's objective economic conditions including net family income, occupation, and adaptation strategies, accompanied with perception of economic hardships, including perception of economic hardship, community hardship and feeling of inflation have a relation with people's opinions toward government policies and performance.The study also revealed that, dissatisfaction in the community as well as feeling of powerlessness, and socio-demographic characteristics affect respondent's political consciousness reflected in their opinions toward government policies and actions.
\end{abstract}

Key words: economic hardship, household adaptation, rural Egypt opinions, trade liberalization.

\section{INTRODUCTION}

The world economy has experienced rapid changes in the past decades. These changes are defined in a variety of ways, as a cycle of crises, economic restructuring, and creation of new international division of labor (Fieldman, 1980). Egypt, as many developing countries, experienced a profound economic transformation during the last decades led by heavy state intervention for a set of "neo-liberal" economic policies, including privatization, macroeconomic stabilization, and trade openness (FAO,2005a\&b).

Much of the research on the topic has assumed that these policies have been largely beneficial. By contrast, the process is neither smooth nor automatic and gains are not necessarily shared by all social groups within the country. The impact of the reforms in terms of economic growth and social welfare has not been as positive as was promised by policy makers. While price inflation has been reduced, it remains too high, and while economic growth has revived, its benefits are unequally distributed and perceived to be concentrated in the hands of wealthier income groups (World Bank, 2002\&FAO, 2005a \&b \& EHDR, 2008).

Despite the recognition of these issues, little attention, however, has been given by policy makers and development agency planners to how rural individuals and households could maintain social life under conditions of economic and social insecurity. Moreover analysts have rarely examined the consequences of these actions on political opinions and equally they neglected the political dimensions of household adaptations.

This study questioned the extent to which rural people's experiences and perceptions of economic conditions are associated with their opinions toward government policies and performance. The study also challenges the dominant sociological assumption that rural people are passive, refrain from participation in activities and these activities might shape their opinions toward government policies and actions.

The study raises several questions to investigate, the type of adaptations of rural families to cope with economic hardship. To what extent rural people are involved in survival 
strategies in their household and in the communities, and what are the social costs of subjective and objective economic hardships. To what extent rural people's experience on economic conditions and perception of economic hardship are related to their opinions and toward government policies and actions.

The main hypothesis is that, the objective economic conditions accompanied with the perception of economic hardships, and dissatisfaction in the community as well as feeling of powerlessness, affect respondents' political consciousness reflected in their opinions toward state policies and actions. It is expected that, individuals who experienced low financial conditions and exhibit greater perception of economic hardship as well as being unsatisfied in the community, and feel higher level of powerlessness will be more likely to hold negative opinions toward government policies and performance.

The study is organized in four parts. The first part, explores the importance of the study for research and theory, and the importance of household in coping with economic hardship, and then outlines (based on literature reviews) various sociological theories that provide basis for understanding how economic change can influence rural people's political opinions. The second part, describes the methodology, including data collection procedures, measurements of variables, and the analytical methods. The third part, presents the findings of descriptive and multiple regression analysis applied, and provides interpretations to the research questions. At the final part, a summary and conclusions of the study results are presented and recommendations for further research are suggested.

\subsection{Background}

Much of the economic research assumed that openness and trade liberalization have been largely beneficial in terms of both resource allocation and economic growth and those relatively open policies contribute to long-run development. (Winters 2000 and McCulloch et al., 2001). However many commentators fear that in the shorter run trade liberalization puts great stress on certain actors in the economy and that even in the longer run successful open regimes may leave some behind in poverty Baker (2003).

Since the early 1980s, significant economic policy reforms in Egyptian agriculture have been instituted in two phases. The first phase (19871989) has reduced government control over production, pricing and distribution. The second phase (1990-1994) consolidated the earlier reforms and eliminates all subsidies of inputs for fertilizers, pesticides, credit and encourages private sector and investment participation (FAO, 2005). These changes have accompanied substantial trade reform, and the new round of WTO (2005) negotiations is poised to bring more changes. Despite the impressive performance in implementing economic reforms Egypt faces considerable challenges in the area of poverty and food security (WTO, 2005\& EHDR, 2008). The majority of the working population in agriculture consists of small family farmers. Consequently, any decline in agricultural production resulting from agricultural trade liberalization can have a major impact on families income.

Some studies have shown that the percentage of the population living below the poverty line might be increasing, especially after the implementation of the first phase of reforms (FAO, 2005; EHDR, 2008). The impact of these trade-related changes on farm households and particularly small ones, have manifested itself in severe economic shocks, including sharp increase in input prices, higher food prices, increase of inflation and poverty.

The sharp increase in food prices in Egypt over the past couple of years has raised serious concerns about the food and nutrition situation of the poor people, about inflation, and about civil unrest (Bouët, 2008).

Several media report that high prices of farm products are good for farmers. But the situation is more complex than that because many farmers and landless laborers are in fact net food buyers. Any increase in income due to the new agricultural policy will be out-weighted by food price increases. Large farmers are not likely to be hurt as some of the proposed changes in agricultural pricing policies will benefit them. However, it is important to note that large farmers ( $>5$ feddans) constitute only $6.5 \%$ of all households (Gustafson, 2008).

Assaad and Roushdy (2005) argued that, the significant increase in inflation that occurred in 2003- 2004 followed a major devaluation of the pound that occurred in January 2003 (in Egypt) has disproportionately affected the poor. Food prices tend to be more affected than other prices in exchange-rate induced price shocks and since food constitutes a larger share of the poors' budget, they tend to be disproportionately affected by such price shocks. Poor households are also less able to adapt to these price shocks, since they tend to have lower labor force participation rates among adults and higher child dependency ratios Assaad and Roushdy (1998).

According to the World Bank's recent poverty assessment update (2002), poverty incidence 
among unpaid family workers, the majority of workers in agriculture, was $27 \%$, which are nearly three times as high as those of wage workers in rural areas, most of whom are casual wage workers. According to the 2006 poverty map poverty is concentrated in the rural areas, while $57.5 \%$ of the population lives in these areas, more than $78 \%$ of the poor and $80 \%$ of the extreme poor live there. The map also shows that poverty is highly concentrated in Upper Egypt, while this region represents $25 \%$ of total population; its share in the extreme poverty is almost $66 \%$. Higher rates of poverty are associated with higher unemployment rate, higher illiteracy rate, greater dependency ratio, and lack of basic services (EHDR, 2008).

\subsection{Rural household adaptation}

Moen and Wethington( 1992) identify family coping strategies as "an intuitively appealing metaphor for family response to structural barriers and stressful events". As such the concept of family strategy has a potential for specifying the processes that link individual lives and patterns of behavior to the broad social change.

Davis (2007), argued that, despite that income diversification is the norm among Egyptian rural households, and that different income generating activities offer alternative pathways out of poverty for households, however, the ability of poor households to participate in potentially more lucrative rural non-farm activities may be limited, given barriers to entry in terms of liquidity or human capital constraints. When that is the case, a vicious circle may be established whereby poor households get relegated to low-return non-farm activities that serve more as "coping strategies" than as a way out of poverty.

Rural people often cope in ways that exacerbate their problems and cause more psychological distress. Adams (2002), in his study in several rural areas in Egypt found that, non-farm income is associated with a reduction in overall rural income inequality in the country. This is often attributed to the lack of access of poorest households to the key productive asset in these areas (Adams 2001\&2002).

One basic asset to which all households have access for generating income is their own labor. Poor households in rural Egypt depend disproportionately on casual labor in the private sector (both agriculture and non-agriculture) and livestock, for generating income (Hopkins, 1989).

A longer-term strategy would also focus on formal sector employment as returns in this sector are higher and it is a crucial sector with regard to helping households move out of poverty (Croppenstedt , 2006).
Selling household assets, particularly productive assets, and acquiring new debt from local merchants and moneylenders, are common survival strategies of poor families.

Other common coping mechanisms are consumption strategies and changes in purchasing practices, which are designed to safeguard food intake, health and nutrition levels as household income falls or as food, clothing, and energy prices rise Lobao and Mayer (1991).

Bouët , (2008) indicated that, higher food prices lead poor people to limit their food consumption and shift to even less-balanced diets, with harmful effects on health in the short and long run, and this will add to their adjustment burden.

The Egyptian Nutrition Institute conducted a study on 100 households from each of Cairo, Assyut and Beheira Governorates to examine the behavior of families as a result of rising food prices. The study revealed that, the rise in income does not cope with the rise in food cost; families resorted to reduction in food and non-food items. As well as consumption of less expensive foods to substitute more expensive ones took place without considering the nutritive value, both quantity and quality of the diet was compromised. All members of the family were affected by reductions in quantity and quality of the diet within the group with the least per capita income; $25 \%$ of laborers stopped consuming meat completely while $50 \%$ of the farmers stopped getting vegetable oil for cooking. More than $80 \%$ of families in this category reduced the amount of meat irrespective of the kind of occupation (Hussein, 1989).

Other coping mechanisms are troubling. According to Egypt 2006 census data, 14.7\% of children between the ages of 6 and 18 mostly in rural areas have never enrolled in basic education or have dropped out of school, amounting to over three million children that have not gained basic literacy skills. Households of Low-income levels force children especially girls to leave school for work to help their families (EHDR , 2008).

\subsection{Economic crisis and political outcomes}

Studies of peasantry have either portrayed peasants as patient, passive and apolitical, or at the other extreme as so full of rebellion, anger and solidarity. These studies are unable to see how resistance attitude is interlined with development and development policies (Brown 1990).

Scott (1987), proposed the following definition for peasant resistance "lower class resistance among peasants is any act(s) by member (s) of the class that is (are) intended either to mitigate or to deny claims (e.g. rents, taxes, deference) made on that class by super ordinate classes (e.g. landlords, 
the government, money lenders) or to advance its own claims vis-à-vis these super ordinate classes". The definition holds three aspects. First, there is no requirement that resistance take the form of collective action. Second, many intended acts of resistance may backfire and produce consequences that were entirely unanticipated. Finally, the definition recognizes the symbolic or ideological resistance (e.g. gossip, slander, rejecting imposed categories, the withdrawal of deference) as an integral part of class-based resistance.

Lobao and Thomas,1990 explained that, two subjective explanations which attempted to argue for people's perception of their conditions at a more subjective level tend to be important in their political attitude. The first, involves assessment of one's potential to survive changing economic conditions and concern about the continuing decline of their financial situation. Uncertainty about future economic survival creates in the individual fear or tension in turn makes him/her more prone to questioning existing social structural arrangement. The second subjective explanation, deals with even a more purely emotional experience by people who are angry, dissatisfied, and frustrated by economic deprivation. Such people express fear, anger, and resentment about life direct resentment toward some social group perceived as responsible of the new situation. The feeling of powerlessness in this case leads to either passivity or endorsement of opposing positions.

The equity model offers another explanation of the relationship between economic changes and political outcomes, and enables us to predict individual's acceptance or resistance to change. The basic idea of equity theory is that individuals evaluate outcomes of change and that those changes considered favorable will be welcomed, while those seen as unfavorable will be resisted (Sen,1984).

Individuals are concerned about their own inputs and outcomes, and the fairness of the exchange among them. If this assessment results in a decline of the net gain, a person will feel distressed and is likely to resist the change. Resistance to change also results when a person perceives inequity compared to other reference groups.

To summarize, three levels of individual assessment of change can be distinguished; (a) resulting change in net gains, or relation of changes in individual inputs to individual outcomes, (b) fair distribution of benefits, and whether they are shared proportionally between different parties, and (c) social comparison of one's own outcomes with those of a reference group.

Brümmer and. Koester (2003) ascertained that effectiveness of policies depends, to a large extent, on the acceptance of policy reform by the population at large. But even if policy reforms are not supported by the society at large, they need to be favored at least by some stakeholders (Brümmer and. Koester 2003). If the public is not convinced that the enacted policy change is in its interest, this may prevent implementation or its traditional attitudes may hinder the achievement of reform.

\section{DATA AND METHODS}

This study was conducted in two villages, ElTalat village at Fayoum Governorate, and in Kafer-Mekawy village at Sharqia Governorate from March to May 2004. To a larger extent, the two villages reflect the feature of their governorates as a whole and the villages are typical of thousands of Egyptian villages in their living conditions. The sampling population is rural families who are exposed to the ongoing changes in the agricultural sector. Cochranes table was used to determine the sample size from the given population of each village. The required representative sample size of the families in the two villages accordingly was 80 families from ElTalat village and 100 families from Kafr-Mekawy village. The required sample size was collected randomly. Fifteen respondents were excluded from the analysis due to insufficient and incomplete responses. The final total sample size became 165 families, 80 from El-Talat village and 85 from Kafr-Mekawy village. Sampling error is controlled by the random selection process. Personal interview was conducted to collect the data from the head of the selected households using a structured pretested questionnaire that contains five parts. The first part; requested information about the household background and the demographic characteristic of respondents. The second; asked the respondents to give information about their experience and perception of the economic hardship during the last year. The third was the attitudinal questions that contained 12 items reflecting the respondent's perceptions and opinions toward government policies and actions.

Data analysis was performed in two sequential steps. The first was using factor analysis to reduce the relevant variables in the data to some common dimensions on the respondent's views toward government policies and performance. The analysis produced two dimensions, one factor, the dependent variable, which contains five items formulating an index. The index reflects high level 
of negative opinions toward government's economic management especially the policies affecting respondent's income, employment, equality and controlling inflation. The other factor reflects feeling of powerlessness which is used as independent variable.

The next step in the analysis was using Ordinary Least Square Regression to explore the relationship between various simultaneous influences of the independent variables upon respondents' opinions.

\subsection{Key variables}

Five sets of factors, relevant to explaining respondent's opinions toward government policies and actions emerged from reviewing the literature. (1) Objective economic conditions, (2) Subjective or perception of economic hardship, (3) The community variables, (4) Feeling of powerlessness and (5) Social demographic characteristic.

The objective economic conditions; were represented by three indicators: total family income, respondent's occupational status, and family survival strategies.

Total family income; was calculated based on information about the size of landholdings and the types of crops, season and yields. It consists of the sources of annual family income, which include income from farm production, income from the main and additional job, children's jobs, and outside resources such as remittances; and family and governmental assistance. Occupation; is measured as the respondent's self defined their occupation. It composed of the respondent's main and secondary jobs. Three main categories are included: work in government office and practice farming was coded as $=1$, farmers only $=2$ and others $=3$. There are several reasons for why the above classification of occupations is selected. First; the bases of politicization occur around farming and government work. Farmers have distinct interest in state subsidization which forms the basis of their livelihood. Farming and government are thus the major bases for political socialization. Second; the sample is very homogenous. Third; for creating less complex but meaningful occupation categories so that the regression analysis would be more parsimonious. As is necessary when categorical variables are used which include the total sample and produce orthogonality. The third category (other) is excluded from the model, the interpretation of this category being implicit from the other one.

Family adaptive strategies; were measured by the index of family adaptations which is based on an earlier index developed by Bultena et al., (1986) and was modified for the Egyptian case. It is created from Yes/ No items reflecting eight adaptations made by the family in the past year to handle financial crisis. The numbers of "Yes" responses to these were summed then divided by the total number of items to calculate the mean of an overall score. Cronbach's Alpha for the internal consistency of the measure was 0.687. Subjective Economic conditions; the other factors that may affect the respondents' attitudes are their perception of economic conditions or an assessment of their own current living conditions. They were represented in three indexes; perception of economic hardship, perception of community hardship, and perception of inflation.

Perception of economic hardship is measured by a commonly used three items scale developed by Pearlin et al. (1981). The scale items asked how often in the past year the respondent felt the household lacked the basic needs including food, clothing, and medical care. Responses were coded; very often $=1$; fairly often $=2$; and never $=3$. Responses were summed to produce the scale. The resulting summed scale has a potential response range from a possible of low 1 to high of 9 . The internal consistency of the scale is substantial, as reflected by the value of 0.797 for Cronbach's Alpha coefficient of reliability.

Perception of community hardship; is measured by an index represents respondent's opinions about the conditions of the basic services and facilities in the community during the last five years including the quality of schools, health centers, water, electricity, transportations, markets, credit, and job facilities. There were three possible responses coded; has it improved $=3$, no change $=2$, or gotten worse $=1$. The responses to the items were summed; the resulting index has a potential responses range from 3 to 24. Alpha coefficient is 0.649 .

Perception of inflation; is measured through the question, did your total household income meet the household necessities, basic needs, under the current increase of the prices? Responses to these questions were coded; Not at all $=4$, we can manage $=3$, almost $=2$, and yes $=1$. Responses were summed to get the mean score.

The Community Variables are included because the community is a setting for production and social consumption and therefore political action and state intervention. The community was represented in three variables, location, satisfaction of financial conditions within the community, and social support in the community.

Location; represents the respondent's residential area, where El-Talat village at Fayoum Governorate was coded 1, Kafr- Mekawy at Sharqia Governorate coded 2.

Satisfaction within the community; is measured 
through two questions, the first asked the respondents about their satisfaction with the current financial condition of their families compared to the other groups in the community.

The second asked their opinions of the current condition of farming in the community. The scale is in the form of rating scale ranging from satisfied $=3$, neutral $=2$ and dissatisfied $=1$. Responses to both questions were summed to form a composite index range from 2 to 6 and Alpha coefficient is 0.835 .

Community support; is measured by an index of items reflecting respondent's participation in local problem solving. The index composed of two questions: the first measures respondents' reaction if the community asks for help in any social services such as food supplies, school, or health care, how much you would help in doing something about it? Responses were ranged from certainly would help $=4$, probably would help $=3$, not sure $=2$, certainly would not help $=1$. The second, measures the respondent's reaction if a neighbor in the community was exposed to unfair financial situation and wrote a complain. Would you certainly support $=4$, probably would support $=3$, probably would not support $=2$, or certainly would not support $=1$. The scale was ranging from a possible of 2 to high of 8 , with a mean score of 5.7 and S.D of .651 Alpha coefficients is 0.786 ,

The Socio-Demographic Characteristics; were presented in three variables.

Age; was measured in years. Education; was measured according to the respondent's formal education in years. Number of children; was measured with the number of children in the household.

Feeling of powerlessness; is an index composed of three items developed through factor analysis including: (1) people like me have no say about what the government does, (2) I have little chance of protecting my personal interest when they conflict with the pressure group, (3) people like myself will never meet their personal goals for improved livelihood. Responses were measured on Likert-like type scales, ranged from: agree $=3$, neutral $=2$, disagree $=1$. The resulting responses were summed to get the mean score, Alpha coefficient is 0.687 .

Attitudes toward government policies and performance; the dependent variable, developed through factor analysis, the scale ranged from agree coded 1 , neutral coded 2 , and disagree coded 3 . The emerged factor reflects respondent's resistance or negative attitude toward government policies and performance in handling various policy problems.

It contains the following five items: (1)increasing the prices of the basic needs and all kinds of farm inputs, threatened our livelihood, the government should do something about increasing living expenses. (2) elimination of farm subsidies put more burden on small farmers, the government should guarantee a minimum price to small farmer to protect them from price changes. (3) elimination of government subsidies on different social services, put more burdens on rural people. (4) unemployment among the younger is increasing, the government should spend for job creation. (5) the gap between the rich and poor has increased, the rich becomes richer and the poor becomes poorer.

Responses to these items are summed to get the mean score of the index. Alpha coefficient for the measure is 0.810

\section{RESULTS AND DISCUSSION}

Descriptive statistics for the ordinal and interval variables are presented in Table (1)

Table (1) shows that the average age of the respondents is 44.3 years and the average education is 2.2 where about $33 \%$ are illiterate,

Table (1) : Means and standard deviation of selected variables

\begin{tabular}{|l|c|c|}
\hline The dependent and independent variables & $\begin{array}{c}\text { Means } \\
\mathbf{N = 1 6 5}\end{array}$ & $\begin{array}{c}\text { Standard deviation } \\
\mathbf{N = 1 6 5}\end{array}$ \\
\hline $\begin{array}{l}\text { The independent variables } \\
\text { Age }\end{array}$ & 44.3 & 11.4 \\
\hline Education & 2.1 & 1.1 \\
\hline Net family income & 4361.5 & 2593 \\
\hline Household adaptive strategies & 0.41 & 0.346 \\
\hline Perception of economic hardship & 1.81 & 1.19 \\
\hline Perception of community hardship & 1.73 & 0.270 \\
\hline Feeling of high inflation & 2.44 & 0.561 \\
\hline Satisfaction in the community & 2.06 & 0.442 \\
\hline Community support & 1.62 & 0.386 \\
\hline Feeling of powerlessness & 1.84 & 01.35 \\
\hline $\begin{array}{l}\text { The dependent variable } \\
\text { Unfavorable opinion toward government policies and actions }\end{array}$ & 2.40 & 0.60 \\
\hline
\end{tabular}


$32 \%$ has less than nine years of education, and $21 \%$ had college degree. The average number of children in the sample is five children.

Concerning the objective economic conditions; the table shows that the majority of the respondents in the sample have relatively low income, where the average annual family income is L.E 4361. When calculating this average income to clarify income per capita for the families, it turns to be less than $\$ 2$ per day ( $\$ 1.96$ ). This result clarify that the majority of the families in the sample are poor. About $1.2 \%$ reported annual income less than L.E 1000, 15\% are making between L.P 1000 to 3000 per year, and only 5\% reported making over L.E 10000 annually.

As for the respondent's occupation, approximately $41.4 \%$ of the respondents work in offices and do farming, while $51 \%$ are farmers only and have no other source of income, and the rest $7.6 \%$ work in other related agriculture activities such as private trading, marketing, crafts and in construction.

The respondents made a number of adaptations to cope with economic hardship during the last year. The mean adjustment score for their adaptations is 0.41 indicating that, on the average, the sample makes about $41 \%$ of the adaptations. The most commonly adaptation used was selling chicken and/or small animal in the market (70.6\%), followed by postponing essential household purchases (57\%), borrowed money $(56 \%)$, sold possessions (53\%), and reduced household utilities $(46 \%)$. About one third of the household members took an additional job (37\%), while $(28 \%)$ reported that young girls were pulled out or forced to quit schools to help in domestic shores and to reduce household expenses, (26\%) of the respondents fell behind in paying debts and $36 \%$ reported that the spouse or one of the family member had to take job outside the village.

Concerning respondent's perception of their economic hardship, about $46 \%, 41 \%$ and $35.5 \%$ of the respondents reported that they could not afford to secure the type of food, clothes and medical care they used to offer their families during the last year consequently. Respondents expressed their feeling of community hardship indicating the worsening conditions of the services and facilities in their communities where, $32 \%$ referred to quality of schools, $70 \%$ to job opportunities, $57 \%$ to health care, $30 \%$ to market facilities, $15 \%$ to clean water, and $28 \%$ mentioned lack of paved roads and affordable transportation.

Regarding respondent's feeling of inflation, about $82 \%$ confirmed that they cannot afford the increasing prices, $11 \%$ reported they can hardly manage, while only $7 \%$ reported that their income offset the increasing prices.

Regarding respondent's satisfaction of their financial conditions, the results show that more than half of the respondents (50.4\%) are unsatisfied of their financial conditions compared to other groups in the community, which indicates higher feeling of inequality within their communities during the last year.

The distribution of respondent's opinions toward government policies and performance showed that, the majority of the respondents $(82 \%)$ agree with the first statement that, they felt threatened and insecure about their livelihood and can not afford the high prices. About 65\% reported that elimination of government subsidies on farm inputs had badly affected their production and put more burdens on the small farmers and those who have limited income, and believe that, the government should guarantees a minimum price to the farmers for their products to protect them from price changes. About $83 \%$ reported the increasing numbers of unemployed youth during the last five years explaining that the government was doing badly in handling job creation; and the government should spend to create more jobs. Nearly $76.3 \%$ of the respondents agreed that the inequality has increased, and the government failed to narrow the income gap between the rich and the poor.

To explore the determinants of rural peoples' opinions toward government policies and action, ordinary Least Square Regression was employed to determine the relationship between, various simultaneous influences of the independent variables upon respondents' opinions. Since no a priori hypotheses had been made to determine the order of entry of the predictor variables, a direct method was used for the multiple linear regression analyses. The correlations between the independent variables and the dependent variable were examined. The correlations were all small to moderate, which indicates that the data are suitably correlated with the dependent variable for examination through multiple linear regressions. Initially, the correlations amongst the independent variables were examined, all correlations were small, and this indicates that multi-colinearity is unlikely to be a problem.

Results of the multiple regression analysis (Table 2) shows that about $28.3 \%$ of the variance in people's opinions toward government policies and actions is explained by the independent variables.

As hypothesized, the objective economic conditions represented in lower income $(B=-$ 0.182 ), and more usages of household adaptations $(B=0.210)$ are significantly related to respondent's 
opinions. This could be attributed to the fact that the negative opinions appears to result more from behavioral attempts to cope with one's situation and position, and using numbers of adaptations to survive under the economic hardship and increasing living expenses. Working as farmers indicates a significant relationship to the respondent's negative opinions $(B=0.113)$ comparing to those working employees and do farming. This may be explained due to the fact that they have relatively higher education and cognitive resources and better skills for dealing with financial pressure which lessens the need for household adjustments. positively related to the level of rejection and negative opinions toward government actions $(B=0.184)$. The government unsuccessful performance in controlling inflation in the short and long run, for keeping the prices down, has affected respondent's attitude and generate a feeling of dissatisfaction about the way the government was handling reform policies. These results suggest that the government has encountered problems in managing the social consequences of the reform program.

Concerning the local community variables, living in El-Talat village at Fayoum Governorate is significantly related to respondent's unfavorable

Table (2): Ordinary Least Square Regression for the respondent's unfavorable opinions toward government policies and action.

\begin{tabular}{|c|c|c|c|}
\hline The independent variables & $\begin{array}{c}\mathrm{b} \\
\mathrm{n}=165\end{array}$ & $\begin{array}{c}\text { Beta coef } \\
n=165\end{array}$ & t state. \\
\hline $\begin{array}{l}\text { Socio-demographic characteristics } \\
\text { Age }\end{array}$ & 0.002 & 0.059 & 4.3382 \\
\hline Education & 0.144 & 0.161 & 6.880 \\
\hline Number of children & -0.023 & 0.054 & 0.955 \\
\hline Objective economic conditions & & & \\
\hline Net family income & -0.133 & -0.182 & 3.506 \\
\hline Employees and do farming & 0.088 & 0.002 & 1.911 \\
\hline Farmers & 0.113 & $0.013^{*}$ & 4.382 \\
\hline Household adaptive strategies & 0.145 & $0.210^{* *}$ & 7.132 \\
\hline Subjective economic hardship & & & \\
\hline Perception of economic hardship & 0.143 & $0.138^{*}$ & 2.342 \\
\hline Perception of community hardship & 0.227 & $0.182 *$ & 6.712 \\
\hline Feeling of high inflation & 0.093 & $0.184^{*}$ & 2.623 \\
\hline Community variables & & & - \\
\hline Location & 0.334 & $0.355 * * *$ & \\
\hline Satisfaction in the community & 0.219 & $0.184 *$ & 3.473 \\
\hline Community support & 0.135 & $0.211 * *$ & 8.273 \\
\hline Feeling of powerlessness & 0.165 & 0.165 & 3.730 \\
\hline R-square $=28.3$ & \multicolumn{3}{|c|}{$F=22.70$} \\
\hline
\end{tabular}

Regarding perceptions of economic hardship, the results confirm our expectations that feeling of more economic hardships $(\mathrm{B}=0.138)$ and community hardship $(\mathrm{B}=0.182)$ are associated significantly (most in the same direction) with respondent's opinions. Respondents who were hit hardest during the last year who feel that the household lacked food, clothing, and medical care they used to have, and those who feel no improvement or deterioration of the quality of the basic services such as school, medical centers, and job opportunities inside the community tend to endorse a substantial opposition and negative opinions toward government policies and actions.

The results also confirm our expectation that respondent's perception of the level of inflation is opinions $(\mathrm{B}=0.355)$. People in El-Talat village seem to have increasing unfavorable and opposing opinions toward government policies and actions, than the residence of Kafr Mekawy. This may be due to the fact that Fayoum is considered one of the poorest governorates in Egypt, and the people were hardest hit by economic crisis, as indicated in Egypt human development report 2008.

Respondent's appraisal of their current economic conditions comparing to other groups in the community as well as the current farming conditions are significantly associated with their negative attitude $(B=0.184)$. Dissatisfaction of income distribution, and inequality between the different groups in the community, as well as pessimism about the current and future farming 
conditions increased the levels of dissatisfaction of government policies and performance.

Social relationships and support among community members have a significant negative relationship to respondent's attitudes $(B=-0.211)$. Respondents, who feel strong social relationships in the community and higher level of community support in times of need, are less likely to have negative opinions toward government policies and actions.

Feeling of powerlessness is significantly associated with increasing negative opinions $(B=0.165)$. Inability to shape one's life and capabilities, lack of self confidence and freedom of choice, may influence and shape their opinions.

Among the demographic characteristics, only education has a significant positive relationship, the higher the education the higher the level of unfavorable opinions $(B=0.161)$. Individuals with relatively higher level of education may have cognitive resources and better understanding of reform policies and the risk of government retrenchment that entails. They are more likely to be dissatisfied and opposing state policies and actions.

\section{Summary and Conclusion}

This study examined rural people's experience and perception of economic hardship and their opinions toward government policies and actions. The study revealed that, rural people's negative opinion is related to several factors including; their experiences of economic hardship, and their perceptions of economic hardship, the worsening conditions of the services and facilities in their communities, in addition to high feeling of powerlessness. Negative opinions toward government policies and actions among rural people arise when their households experience adverse financial demands and when their perception of inequality and fair sharing of benefits is increasing, in addition to increasing inflation.

Liberalization policies and the free market mechanisms have not been able to solve the current economic problems without a determination and political will to introduce corresponding reforms in the policy-making process. As El-Ghonemy (1993). puts it "plurality in economic activities within free market has to be linked to a political playwright in the policy formulation". One way is to combine political with economic reform, to offer increased participation, and truly elected representatives of the rural people. Greater and true political participation of farmers could provide an important offset to the large, well organized greater participation by the citizenry.
Supporting agriculture is a key factor in long term relief from economic restructuring and potential rising food prices. The government should revitalize its support for research, innovation, and extension to transform small farm agriculture. These investments not only have high returns in terms of agricultural growth, but also in reducing poverty.

Empowering small-scale farmers and invest in people; for longer term impact of economic restructuring, a substantial need to invest in social protection measures is essential, such as cash transfer programs, pension systems and employment programs. Preventative health and nutrition programs targeted vulnerable groups should be scaled up to ensure national coverage. In addition, providing improved seeds, fertilizer, credit, and other resources for small-scale farmers would quickly improve production, increase incomes, and lower the prices. School feeding programs in rural areas, can play an important role in increasing school enrollment and in retaining children in school and enhancing their achievement. These programs would reduce the vulnerability of poor people and enhance their long-term productive capacity.

\section{REFERENCES}

Adams R. (2001). Non-Farm Income, Inequality and Poverty in Rural Egypt and Jordan. Policy Research Working Paper 2572, Washington DC: WB

Adams R. (2002). Non-farm Income, Inequality and Land in Rural Egypt. Economic Development and Cultural Change 50(2): 339363.

Assaad R. and Roushdy R. (1998). Poverty and Poverty Alleviation Strategies in Egypt Ford Foundation.

Assaad A. and Roushdy R. (2005). The Population Council, Cairo, 2005.

Baker A. (2003). Why is Trade Reform so Popular in Latin America? A Consumption-Based Theory of Trade Policy Preferences. In World Politics 55 (April):423-55.

Bouët A. (2008). The Expected Benefits of Trade Liberalization for World Income and Development. International Food Policy Research Institute.

Brown N. (1990). Peasant polititcs in modern Egypt: The struggle against the state. Yale University press.

Brümmer B. and. Koester U. (2003). "Institutional changes for agricultural and rural development in the CEEC and CIS 
region. Electronic Journal of Agricultural and Development Economics, Vol. 3, No. 2, 2006, pp. 144-179.

Bultena G., P. lasely and J. Geller (1986).The farm crisis patterns and impact of financial distress among lowa farm families. Rural Sociology 51 (winter) :391-405.

Croppenstedt A. (2006). Household Income Structure and Determinants in Rural Egypt. ESA Working Paper No. 06-02.

Davis J.(2007). Rural non-farm livelihoods in transition economies: emerging issues and policies. Electronic Journal of Agricultural and Development Economics (eJADS), vol.3:180-224.

EHDR (2008). United Nation Development Program,. Egyptian Human Development Report, Ministry of Planning Egypt.

El-Ghonemy R. (1993). Food and rural development in North Africa. Westview press publications .

FAO (2005a). The situation of Food in the world.

FAO (2005b). The State of Food and Agriculture: Agricultural trade and poverty, can trade work for the poor?.FAO, Rome.

Feildman H. (1980). Household production and the National Economy: Concept for the Analysis of Agrarian Formation. Journal of peasant studies, 7(3),58-84

Gustafson D. (2008). Behavior of Families as Result of Rising Food Prices; (Current Consumption (Food) Future Consumption (Health), FAO, 2008.

Hopkins, N. (1989) Small Farmer Households and Agricultural Sustainability in Egypt. in Sustainable agriculture in Egypt. Faris. A. \& Khan, $\mathrm{H}$.

Hussein A. (1989). Impact of the agricultural policy and investment allocation patterns on the nutrition status of the Egyptians. The Egyptian nutrition institute, FAO, Roma.

Lobao L.and Thomas P. (1990) .Political beliefs in an area of economic decline: farmers attitudes toward state intervention, trade, and food security. Rural sociology 57:453-475.

Lobao L. and K. Mayer (1991). Consumption Patterns, Hardship, and Stress Among Farm Household Rural Sociology and Development, (5) 191-209.

McCulloch N., Winters L. and Cirera X. (2001). Trade Liberalization and Poverty: A Handbook. London, Center for Economic and Policy Research.

Moen P. and Wethington E. (1992).The concept of family adaptive strategies Annual Review of Sociology 18:233-251.

Pearlin L., Menaghan E.G. and Liebrman M.A. (1981). The stress process. Health and social behavior 22(4):337-356.

Scott J.(1987). The moral economy of the peasant: Rebellion and subsistence in southeast Asia.Amazon. Available at www.amazon. com.

Sen, A. K. (1984). .Rights and capabilities. in Resources, Values and Development, Oxford: Basil Blackwell: 307-24.

Winters A. (2000). Trade, Trade Policy and Poverty: What are the Links? Center for Economic Policy Research London.

World Trade Organization, WTO (2005). Trade policy Review, Egypt, trade policies by sector. Report wt/Tpr/s/150. Available at http://www.wto.org.

World Bank(2002). Empowerment and poverty reduction, WB Washington DC.

World Bank(2005). Globalization and the challenge for developing countries. Policy research working paper, June 2005. 


\section{خبرات وادراك وآراء الريفيين للمعاناة الاقتصادية \\ ( دراسة في قريتين مصريتين )}

\section{عزة تهامى البندارى}

قسم الاجتماع الريفى و الارشاد الزر اعى ـكلية الزراعة ـجامعة القاهرة- الجيزة ـمصر

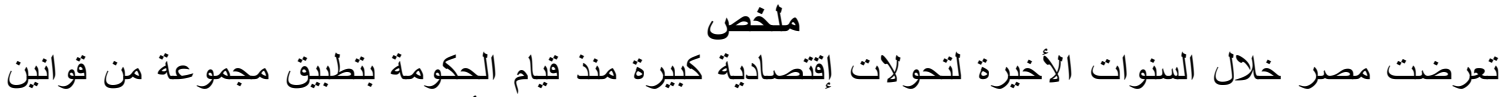

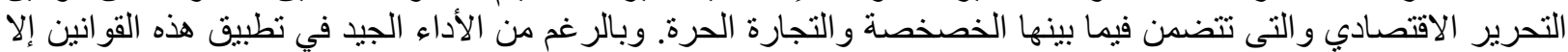

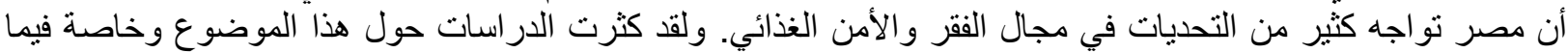

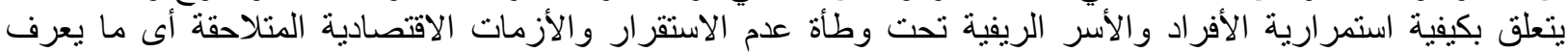

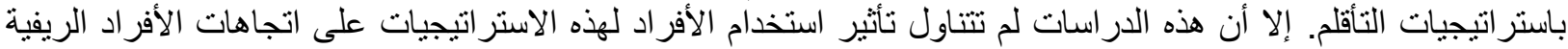

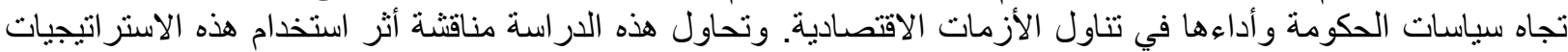

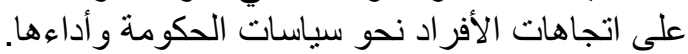

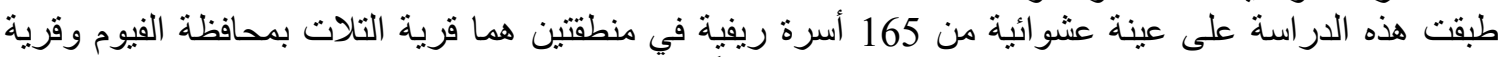

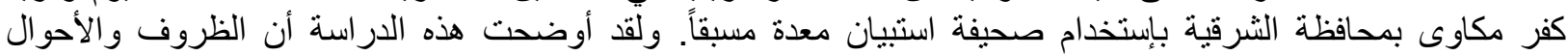

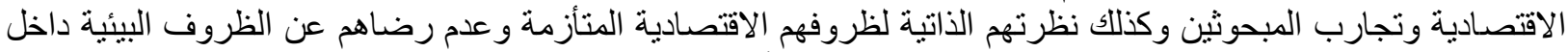

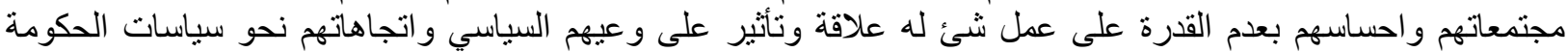
و أداءها.

المجلة العلمية لكلية الزراعة - جامعة القاهرة - المجلا (60) العدد الأول (يناير 2009): 1-11. 